\title{
Analisis Faktor-Faktor Yang Mempengaruhi Struktur Modal Pada Perusahaan Perkebunan Yang Terdaftar Di Bursa Efek Indonesia
}

\author{
Muhammad Ridho Fitrianda Pratama1', Yasir Arafat ${ }^{2}$, Mursalin ${ }^{3}$ \\ ${ }^{1}$ Fakultas Ekonomi dan Bisnis Universitas PGRI Palembang \\ ${ }^{2}$ Fakultas Ekonomi dan Bisnis Universitas PGRI Palembang, yasir arafat14@yahoo.com \\ ${ }^{3}$ Fakultas Ekonomi dan Bisnis Universitas PGRI Palembang, Mursalin@univpgri-palembang.ac.id
}

\begin{abstract}
The purpose of this study is to determine the effect of business risk, non-debt tax shield, profitability on the capital structure of plantation companies listed on the Indonesia Stock Exchange (IDX) for the period 2011-2016. Data The financial statements used are financial reports that have been published in the Indonesian Capital Market Directory (ICMD). The population in this study were all plantation companies listed on the Indonesia Stock Exchange in 2011-2016 totaling 16 companies. In this study the authors used a sample of 10 plantation companies selected by purposive sampling. The data collection method uses literature study and documentation. The analysis technique used in this research is multiple linear regression with the help of SPSS 22.0 for windows software. The results showed that 1) Taken together, business risk, non-debt tax shield and profitability have a significant effect on capital structure. 2) Partially the independent variables (business risk, non-debt tax shield and profitability) have no significant effect on the capital structure of plantation companies listed on the Indonesia Stock Exchange for the 2011-2016 period.
\end{abstract}

Keywords: Business Risk, Non-Debt Tax Shield, Profitability and Capital Structure.

\section{ABSTRAK}

Tujuan penelitian ini mengetahui pengaruh risiko bisnis, non-debt tax shield, profitabilitas terhadap struktur modal pada perusahaan perkebunan yang terdaftar di Bursa Efek Indonesia (BEI) periode tahun 2011-2016. Data Laporan keuangan yang digunakan adalah laporan keuangan yang telah dipublikasikan di dalam Indonesia Capital Market Directory (ICMD). Populasi dalam penelitian ini adalah seluruh perusahaan perkebunan yang terdaftar di Bursa Efek Indonesia pada tahun 2011-2016 berjumlah 16 perusahaan. Dalam penelitian ini penulis menggunakan sampel sebanyak 10 perusahaan perkebunan yang dipilih secara purposive sampling. Metode pengumpulan data menggunakan studi pustaka dan dokumentasi. Teknik analisis yang digunakan dalam penelitian ini adalah regresi linier berganda dengan bantuan software SPSS 22.0 for windows. Hasil penelitian menunjukkan bahwa 1) Secara bersama-sama risiko bisnis, non-debt tax shield dan profitabilitas berpengaruh signifikan terhadap struktur modal. 2) Secara parsial variabel independen (risiko bisnis, non-debt tax shield dan profitabilitas) tidak berpengaruh signifikan terhadap struktur modal pada perusahaan perkebunan yang terdaftar di Bursa Efek Indonesia periode 2011-2016.

Kata Kunci : Risiko Bisnis, Non-Debt Tax Shield, profitabilitas dan Struktur Modal.

\section{A. PENDAHULUAN}

Perusahaan perkebunan di Indonesia memiliki peran penting bagi perekonomian nasional. Pada saat terjadi krisis ekonomi pada periode tahun 1997 yang mana banyak perusahaan mengalami kesulitan keuangan dan kebangkrutan, pada saat itu hampir seluruh perusahaan perkebunan mencatat keuntungan yang cukup besar akibat pelemahan rupiah. Tahun 2008 menurut Direktorat Jenderal Perkebunan (2009) devisa yang dihasilkan sub sector perkebunan yang merupakan bagian intergral dari sektor pertanian adalah sebesar US\$22,8 milyar. Komoditi kelapa sawit merupakan salah satu andalan komoditi pertanian Indonesia yang 
pertumbuhannya sangat cepat dan mempunyai peran strategis dalam perekonomian nasional.

Perusahaan didirikan dengan dengan tujuan utama adalah untuk memaksimalkan kemakmuran dan keuntungan bagi para pemegang sahamnya, untuk mencapai tujuan perusahaan dengan meningkatkan nilai perusahaan tersebut. Tujuan lain dari perusahan yaitu mendapatkan laba dari tahun ke tahun serta menjaga kelangsungan hidup perusahaan. Apabila suatu perusahaan dalam memenuhi kebutuhan dananya mengutamakan sumber dari perusahaan, maka akan sangat mengurangi ketergantungannya kepada pihak luar.

Perusahaan tidak akan lepas dari masalah pengelolaan dana yang akan digunakan untuk membiayai kegiatan investasinya maupun operasional. Masalah pengelolaan dana berhubungan dengan bagaimana perusahaan menentukan sumber dana yang akan digunakan dalam menjalankan serta mengembangkan kegiatan investasinya maupun kegiatan operasional perusahaan. Manajer keuangan mengambil peran untuk menentukan sumber dana yang akan digunakan. Keputusan pemenuhan dana mencakup berbagai pertimbangan, apakah perusahaan akan menggunakan sumber dana internal yang berasal dari hasil kegiatan operasi perusahaan berupa laba ditahan, atau menggunakan sumber dana eksternal yang berasal dari para kreditur dan investor. Sumber dana sangat terkait dengan manajemen pendanaan.

Keputusan pendanaan yang dilakukan secara tidak cermat akan menimbulkan biaya tetap dalam bentuk biaya modal yang tinggi, yang selanjutnya dapat berakibat pada rendahnya profitabilitas perusahaan. Keputusan struktur modal secara langsung juga berpengaruh terhadap besarnya risiko yang ditanggung pemegang saham serta besarnya tingkat pengembalian atau tingkat keuntungan yang diharapkan (Brigham dan Houston, 2006:17). Keputusan struktur modal yang diambil oleh manajer tersebut tidak saja berpengaruh terhadap profitabilitas perusahaan, tetapi juga berpengaruh terhadap risiko keuangan yang dihadapi perusahaan.

Pengambilan keputusan yang berkaitan dengan struktur modal perusahaan sebaiknya melalui analisis dan perhitungan komposisi struktur modal yang mendekati optimal sehingga memberikan nilai perusahaan yang maksimal dan biaya modal yang minimal. Peningkatan nilai perusahaan ini pada akhirnya akan meningkatkan kesejahteraan para pemegang saham. Struktur modal diukur dan dinyatakan berdasarkan jumlah dari berbagai sumber permodalan. Mengenai jumlah dan komposisi tiap-tiap jenis sumber permodalan yang diperlukan masing-masing perusahaan saat ini tidak ada aturan yang pasti karena struktur dipengaruhi oleh sifat, jenis dan kondisi serta biaya modal dari masing-masing komponen sumber permodalan. Struktur modal haruslah dibentuk sedemikian rupa sehingga dapat menjamin stabilitas financial agar perusahaan dapat menghasilkan keuntungan yang diinginkan. Oleh karena itu perusahaan harus menetapkan struktur modal yang optimal.

Suatu struktur modal dikatakan optimal apabila dengan tingkat resiko tertentu dapat memberikan nilai perusahaan yang maksimal. Tujuan utama perusahaan adalah meningkatkan nilai perusahaan melalui peningkatan kemakmuran pemiliki atau pemegang saham (Brigham dan Houston, 2006:19). Nilai perusahaan merupakan harga yang bersedia dibayar oleh calon pembeli apabila perusahaan tersebut dijual. Bagi perusahaan yang menerbitkan saham di pasar modal, harga saham yang diperjualbelikan di bursa merupakan indikator nilai perusahaan (Husnan dan Pudjiastuti, 2012:7). 
Proporsi antara total debt (total hutang) dan total shareholder's equity (total modal sendiri) atau Debt Equity Ratio (DER) disebut struktur modal. Total debt merupakan total liabilities (total utang jangka panjang maupun utang jangka pendek), sedangkan total shareholder's equity merupakan total modal sendiri (total modal saham yang disetor dan laba yang ditahan) yang dimiliki perusahaan. Rasio ini menunjukkan komposisi dari total hutang terhadap total ekuitas. Semakin tinggi DER menunjukkan komposisi total hutang semakin besar dibanding dengan total modal sendiri, sehingga berdampak semakin besar beban perusahaan terhadap pihak luar (kreditur).

Faktor-faktor yang mempengaruhi keputusan struktur modal menjadi hal yang penting sebagai dasar pertimbangan keputusan struktur modal. Faktor-faktor yang dapat mempengaruhi keputusan struktur modal perusahaan secara umum adalah stabilitas penjualan, struktur aktiva, leverage operasi, tingkat pertumbuhan, profitabilitas, pajak, pengendalian, sikap manajemen, sikap pemberi pinjaman dan agen pemberi peringkat, kondisi pasar, kondisi internal perusahaan, dan fleksibilitas keuangan (Brigham dan Houston, 2006:42). Dalam penelitian ini akan menggunakan faktor yang mempengaruhi struktur modal antara lain, risiko bisnis (business risk), non-debt tax shield, profitabilitas, kepemilikan institusional (institutional ownership), ukuran perusahaan.

Kepemilikan Institusional merupakan bentuk kepemilikan saham suatu perusahaan oleh satu atau lebih institusi (lembaga). Kepemillikan institusional dapat berperan dalam memonitoring perilaku manajer, sehingga managerial opportunism lebih rendah, yang akan mengurangi konflik agensi. Dengan tingkat pengawasan yang tinggi, akan menurunkan biaya monitoring serta perusahaan akan lebih berhatihati dalam pengambilan keputusan (Mardinawati, 2010). Penelitian Werdiniarti (2007) menemukan bahwa kepemilikan institusional memiliki pengaruh negatif terhadap struktur modal. Sedangkan Mardinawati (2010) menemukan bahwa kepemilikan institusional tidak berpengaruh secara signifikan terhadap struktur modal. Ukuran perusahaan merupakan ukuran atau besarnya suatu aset yang dimiliki oleh suatu perusahaan. Penelitian Mardinawati (2010) menemukan bahwa 9 ukuran perusahaan berpengaruh negatif terhadap struktur modal. Sedangkan Sumani dan Rachmawati (2012) menemukan bahwa ukuran perusahaan tidak berpengaruh terhadap struktur modal.

\section{B. KAJIAN TEORI}

\section{1) Teori Struktur Modal}

Tujuan dari teori struktur modal memberikan landasan berpikir untuk mengetahui struktur modal yang optimal. Suatu struktur modal dikatakan optimal apabila dengan tingkat resiko tertentu dapat memberikan nilai perusahaan yang maksimal. Tujuan utama perusahaan adalah meningkatkan nilai perusahaan melalui peningkatan kemakmuran pemilik atau pemegang saham (Brigham dan Houston, 2006:19). Nilai perusahaan merupakan harga yang bersedia dibayar oleh calon pembeli apabila perusahaan tersebut dijual. Bagi perusahaan yang menerbitkan saham di pasar modal, harga saham yang diperjualbelikan di bursa merupakan indikator nilai perusahaan (Husnan dan Pudjiastuti, 2012:7). Teori mengenai struktur modal telah banya dibicarakan oleh para peneliti. Berikut ini akan diuraikan mengenai teori-teori tersebut. 


\section{2) The Trade Off Model}

Teori ini merupakan keseimbangan antara keuntungan dan kerugian atas penggunaan hutang, dimana dalam keadaan pajak nilai perusahaan akan naik minimal dengan biaya modal yang minimal.

\section{3) Pecking Order Theory}

Teori ini digunakan untuk menjelaskan keterkaitan variabel independen yaitu profitabilitas, ukuran perusahaan dan non-debt tax shield terhadap variabel dependen yaitu struktur modal. Perusahaan dengan return on assets yang tinggi, umumnya menggunakan hutang dalam jumlah yang relatif kecil, karena dengan rate of return yang tinggi, kebutuhan dana dihasilkan secara internal dari laba ditahan (Weston dan Brigham, 2006:713). Sehingga dapat dikatakan profitabilitas berpengaruh negatif terhadap struktur modal. Perusahaan yang berukuran besar dapat membiayai investasinya dengan mudah melalui pasar modal karena kecilnya informasi asimetri yang terjadi. Investor dapat memperoleh lebih banyak informasi dari perusahaan besar jika dibandingkan dengan perusahaan kecil. Jadi, dengan diperolehnya dana melalui pasar modal menjadikan proporsi utang menjadi semakin kecil dalam struktur modalnya. Dengan demikian ukuran perusahaan berpengaruh negatif terhadap struktur modal. Non-debt tax shield sebagai penentu struktur modal bukan dari hutang, berupa pembebanan biaya depresiasi terhadap laba dan rugi. Semakin besar depresiasi akan menyebabkan semakin besar penghematan pajak penghasilan dan semakin besar cash flow perusahaan. Dengan demikian, suatu perusahaan yang memiliki non-debt tax shield tinggi cenderung akan menggunakan hutang yang lebih rendah. Sehingga dapat dikatakan non-debt tax shield berpengaruh negatif terhadap struktur modal.

Pecking Order Theory menurut Megginson dan Gitman (2006:458-459) secara spesifik perusahaan mempunyai urutan preferensi dalam memilih sumber pendanaan, yaitu :

a. Perusahaan lebih memilih untuk menggunakan sumber dana dari dalam atau pendanaan internal daripada eksternal. Dana internal tersebut diperoleh dari laba ditahan yang dihasilkan dari kegiatan operasional perusahaan.

b. Jika pendanaan Eksternal diperlukan, maka perusahaan akan memilih pertama kali mulai dari sekuritas yang paling aman, yaitu hutang yang paling rendah risikonya, turun ke hutang yang lebih beresiko, sekuritas hybrid seperti oblikasi konversi, saham preferen, dan yang terakhir saham biasa.

c. Terdapat kebijakan deviden yang konstan, yaitu perusahaan akan menetapkan jumlah pembayaran deviden yang konstan, tidak terpengaruh seberapa besarnya perusahaan tersebut untung atau rugi.

\section{4) Equity Market Timing}

Teori ini mengemukakan bahwa perusahaan - perusahaan akan menerbitkan equity pada saat market value tinggi dan akan membeli kembali equity pada saat market value rendah. Praktik inilah yang disebut Equity Market Timing. Tujuan dari melakukan equity market timing ini adalah untuk mengeksploitasi fluktuasi sementara yang terjadi pada cost of equity terhadap cost of other forms of capital.

\section{5) Komponen Struktur Modal}

Menurut Riyanto (2008:227) komponen struktur modal tersusun atas modal asing dan modal sendiri, berikut ini penjelasan lengkapnya : 
a) Modal Asing

Modal asing atau utang merupakan modal yang asalnya dari luar perusahaan yang bersifat sementara bekerja pada perusahaan dan untuk perusahaan yang terkait modal tersebut adalah hutang yang hingga waktu yang harus dibayar kembali.

Modal asing atau utang bisa dibedakan menjadi tiga jenis yakni berikut ini :

1) Utang Jangka Pendek.

Utang jangka pendek yaitu modal asing yang pengembalian waktunya paling lama adalah satu tahun.

2) Utang Jangka Menengah.

Utang jangka menengah yaitu utang yang jangka pengembalian waktunya lebih dari 1 tahun atau kurang dari 10 tahun. Utang jangka menengah dapat dikategorikan menjadi 2 yaitu, Term Loan dan Leasing Term Loan.

3) Utang Jangka Panjang.

Utang jangka panjang yaitu utang yang jaangka pengembalian waktunya lebih dari 10 tahun. Bentuk utang jangka panjang diantaranya pinjaman obligasi dan pinjaman hipotek.

b) Modal Sendiri

Modal sendiri atau ekuitas adalah modal yang asalnya dari pemilik perusahana dan ditanam dalam perusahaann dalam jangka waktu yang tidak menentu lamanya. Modal sendiri diharapkan tetap berada dalam perusahaan untuk jangka waktu yang tidak mempunyai batas, sedangkan modal pinjaman mempunyai jatuh tempo. Dalam suatu perusahaan modal sendiri bisa dibedakan dalam beberapa jenis, antara lain :

1) Modal Saham.

Modal saham merupakan tanda bukti pengembalian bagian atau peserta dalam sebuah perusahaan. Terdapat jenis-jenis dari saham yakni saham biasa (common stock), saham preferen (Prefed Stock), Saham kumulatif (cumulative preferred stock) dan lain sebagainya.

2) Cadangan.

Cadangan yang dimaksud disini adalah sebagai cadangan yang dibuat dari perolehan keuntungan yang didapat oleh perusahaan selama rentang waktu yang lalu atau dari tahun yang berjalan. Cadangan yang masuk dalam modal sendiri diantaranya cadangan ekspansi, cadangan modal kerja, cadangan selisih kurs, cadangan untuk menampung hal-hal atau peristiwa-peristiwa yang tidak diduga sebelumnya (cadangan umum).

3) Laba Ditahan.

Keuntungan yang didapat oleh sebuah perusahaan bisa beberapanya dibayarkan sebagai dividen dan beberapanya ditahan oleh perusahaan. Jika perusahaan menahan keuntungan tersebut telah dengan tujuan tertentu, maka dibuatlah cadangan sebagaimana yang sudah diuraikan. Jika perusahaan belum memiliki tujuan tertentu tentang pemakaian keuntungan tersebut, maka keuntungan tersebut adlaah keuntungan yang ditahan.

\section{6) Faktor - Faktor yang Mempengaruhi Struktur Modal}

Brigham dan Houston (2006:42) menunjukkan faktor-faktor yang umumnya dipertimbangkan oleh perusahaan ketika mengambil keputusan mengenai struktur modal yaitu, antara lain : 
a) Stabilitas Penjualan.

Perusahaan dengan stabilitas penjualan yang relatif stabil dapat lebih aman memperoleh lebih banyak pinjaman dan menanggung beban tetap yang lebih tinggi dibandingkan dengan perusahaan yang penjualannya tidak stabil.

b) Struktur Aktiva.

Perusahaan yang aktivanya sesuai untuk dijadikan kredit cenderung lebih banyak menggunakan hutang.

c) Leverage Operasi.

Perusahaan dengan leverage operasi yang lebih kecil cenderung lebih mampu untuk memperbesar leverage keuangan karena akan mempunyai risiko bisnis yang lebih kecil.

d) Tingkat Pertumbuhan.

Tingkat pertumbuhan ditunjukkan dengan peningkatan penjualan dari periode ke periode. Dengan semakin meningkatnya ukuran perusahaan dari penjualan, maka kreditor akan semakin percaya dengan kinerja perusahaan, sehingga dapat meningkatkan dana untuk operasional perusahaan.

e) Profitabilitas.

Tingkat pengembalian yang tinggi memungkinkan perusahaan membiayai sebagian besar kebutuhan pendanaan mereka dengan dana yang dihasilkan secara internal.

f) Pajak.

Bunga merupakan beban yang dapat dikurangkan untuk tujuan perpajakan dan pengurangan tersebut sangat bernilai bagi perusahaan yang terkena tarif pajak yang tinggi.

g) Pengendalian.

Pengaruh hutang melawan saham terhadap posisi pengendalian manajemen dapat mempengaruhi struktur modal. Pertimbangan pengendalian tidak selalu menghendaki penggunaan hutang atau ekuitas karena jenis modal yang memberi perlindungan terbaik bagi manajemen bervariasi dari suatu situasi ke situasi lain. Jika posisi manajemen sangat rawan, situasi pengendalian perusahaan akan dipertimbangkan.

h) Sikap Manajemen.

Sejumlah manajemen cenderung konservatif daripada manajemen lainnya, sehingga menggunakan jumlah hutang yang lebih kecil daripada rata-rata perusahaan dalam industri yang bersangkutan, sementara manajemen lain lebih cenderung menggunakan banyak hutang dalam usaha mengejar laba yang tinggi.

i) Sikap Pemberi Pinjaman dan Lembaga Penilai Peringkat.

Sikap para pemberi pinjaman dan perusahaan penilai peringkat (rating agency) sering kali mempengaruhi keputusan struktur keuangan.

j) Kondisi Pasar.

Kondisi pasar saham dan obligasi mengalami perubahan jangka panjang dan jangka pendek yang sangat berpengaruh terhadap struktur modal perusahaan yang optimal.

k) Kondisi Internal Perusahaan.

Perusahaan pada suatu saat perlu menanti waktu yang tepat untuk mengeluarkan saham atau obligasi tergantung dari kondisi internnya. 
I) Fleksibilitas Keuangan.

Mempertahankan fleksibilitas keuangan dilihat dari sudut pandang operasional berarti mempertahankan kapasitas cadangan yang memadai untuk melakukan pinjaman.

Dalam penelitian ini hanya beberapa variabel yang diteliti bagaimana pengaruhnya terhadap struktur modal perusahaan, seperti risiko bisnis, non-debt tax shield, profitabilitas.

\section{a) Risiko Bisnis}

Risiko bisnis dalam artian berdiri sendiri adalah suatu fungsi dari ketidakpastian yang inheren di dalam proyeksi pengembalian atas modal yang diinvestasikan di dalam suatu perusahaan (Brigham dan Houston, 2006:9). Secara konsep perusahaan memiliki sejumlah risiko yang inheren di dalam operasinya, salah satu penyebabnya adalah ketidakpastian arus kas dalam suatu investasi.

Suatu perusahaan mempunyai ketidakpastian arus kas disebabkan adanya faktor operating leverage. Operating leverage menunjukkan penggunaan aktiva yang menimbulkan biaya tetap (fixed cost). Biaya tetap adalah biaya yang tidak berubah meskipun aktivitas perusahaan Dengan demikian perusahaan yang mempunyai operating leverage tinggi, dapat diartikan sebagai perusahaan yang mempunyai risiko yang tinggi. Jadi, semakin besar Degree of Operating Leverage (DOL) berarti semakin besar variasi keuntungan akibat perubahan penjualan. Perusahaan dengan DOL yang tinggi berarti bahwa ada sedikit saja penurunan penjualan akan berakibat pada penurunan Earning Before Interest and Tax (EBIT) yang cukup besar.

Dengan adanya hutang maka, beban bunga dari hutang tersebut akan semakin menurunkan penghasilan bersih setelah bunga dan pajak. Sehingga terdapat hubungan negatif antara resiko bisnis dengan struktur modal. Dalam penelitian ini risiko bisnis digambarkan dengan mengukur Degree of Operating Leverage (DOL), dihitung dengan cara membagi persentase perubahan EBIT dengan persentase perubahan penjualan (Firnanti, 2011), yang dirumuskan sebagai berikut.

$$
\text { Risiko Bisnis }=\frac{\% \Delta \text { EBIT } / \text { EBIT }}{\% \Delta \text { Penjualan } / \text { Penjual }}
$$

\section{b) Non-Debt Tax Shield}

Non-Debt Tax shield adalah suatu perlindungan pajak perusahaan yang bukan berasal dari hutang. Perlindungan pajak perusahaan mencakup kredit pajak investasi, penyisihan penyusutan dan penyisihan untuk deplesi oil. Jadi, dalam melakukan efisiensi penghitungan pajak selain dengan membebankan biaya bunga hutang, perusahaan dapat memanfaatkan keuntungan/perlindungan pajak melalui fasilitas perpajakan melalui beban depresiasi.

Perusahaan akan memilih tingkat hutang yang berkorelasi negatif dengan tingkat perlindungan pajak lain seperti kredit pajak investasi, penyusutan (depresiasi). Dengan demikian, suatu perusahaan yang memiliki non-debt tax shield yang tinggi cenderung akan menggunakan tingkat hutang yang lebih rendah, sehingga variabel non-debt tax shield berhubungan negatif terhadap struktur modal. Non-debt tax shield merupakan hasil dari beban depresiasi (depreciation expense) dibagi dengan total aset yang dirumuskan sebagai berikut : 


$$
\text { Non-deb tax shield }=\frac{\text { Beban Depresiasi }}{\text { Total Aset }}
$$

\section{c) Profitabilitas}

Dalam penelitian ini profitabilitas diproksikan dengan ROA. ROA merupakan rasio yang menunjukkan berapa banyak laba bersih setelah pajak dapat dihasilkan dari (rata-rata) seluruh kekayaan yang dimiliki perusahaan. Sehingga, apabila ROA meningkat berarti profitabilitas perusahaan meningkat, sehingga dampak akhirnya adalah peningkatan profitabilitas yang dinikmati oleh pemegang saham. Dengan demikian, perusahaan yang profitabilitasnya tinggi akan menggunakan dana pinjaman yang sedikit, sehingga terdapat hubungan negatif antara profitabilitas terhadap struktur modal. ROA didefinisikan sebagai perbandingan dari laba bersih setelah pajak dengan total aktiva, yang dirumuskan sebagai berikut :

ROA = Laba Setelah Pajak

Total Aset

\section{METODE PENELITIAN}

Soeratno dan Arsyad (1999:69-70) menyatakan bahwa :

1) Metode Kualitatif yaitu suatu analisa data yang bukan termasuk angka dan biasanya sulit diatur.

2) Metode Kuantitatif yaitu suatu analisa data yang dinyatakan dalam angka dan dapat dihitung dengan rumus statistik.

Berdasarkan definisi di atas metode yang akan digunakan dalam penelitian ini adalah metode kuantitatif.

\section{a) Variabel Penelitian}

Variabel dalam penelitian ini ada dua macam, yaitu :

* Variabel Independen

Menurut Sugiyono (2015:59) variabel independen atau variabel bebas merupakan variabel yang mempengaruhi atau yang menjadi sebab perubahannya atau timbulnya variabel dependen (terikat). Variabel independen atau variabel bebas dalam penelitian ini adalah $\mathrm{X}_{1}$ (Risiko Bisnis), variabel $\mathrm{X}_{2}$ (Non Debt Tax Shield), dan variabel $\mathrm{X}_{3}$ (Profitabilitas).

* Variabel Dependen

Menurut Sugiyono (2015:59) variabel dependen atau variabel terikat merupakan variabel yang dipengaruhi atau yang menjadi akibat, karena adanya variabel bebas. Variabel dependen dalam penelitian ini adalah Struktur Modal (Y).

\section{b) Populasi dan Sampel}

* Populasi

Populasi dalam penelitian ini adalah Perusahaan sub sektor Perkebunan.

* Sampel

Menurut Sugiyono (2015:81). Sampel adalah bagian dari jumlah dan karakteristik yang dimiliki oleh populasi tersebut. Metode dalam pengambilan sampel ini menggunakan metode purposive sampling, dengan kriteria: 
Perusahaan perkebunan menerbitkan atau mempublikasikan laporan keuangannya lengkap berisi informasi yang dibutuhkan oleh investor periode tahun 2011-2016.

> Perusahaan perkebunan yang menyajikan informasi lengkap sesuai dengan data yang dibutuhkan dalam penelitian.

- Perusahaan perkebunan menampilkan data dan informasi yang digunakan untuk menganalisis faktor-faktor yang mempengaruhi ketepatan waktu pelaporan keuangan

\section{c) Teknik Pengumpulan Data}

* Observasi (Pengamatan).

Basrowi (2012) Observasi adalah suatu teknik yang dilakukan dengan cara mengadakan pengamatan secara diteliti serta pencatatan secara sistematis.

* Interview.

Esterberg (2013) mendefinisikan interview merupakan pertemuan dua orang untuk bertukar informasi dan ide melalui tanya jawab, sehingga dapat dikonstruksikan maksa dalam suatu topik tertentu.

* Dokumentasi.

Dokumen merupakan catatan peristiwa yang sudah berlalu. Dokumen bisa berbentuk tulisan, gambar, atau karya - karya manumental dari seseorang.

* Studi Pustaka.

Dalam penelitian mengkaji informasi teori yang diperoleh dari literatur, artikel, jurnal - jurnal dan hasil penelitian terdahulu sehingga peneliti dapat memahami literatur yang berkaitan dengan penelitian yang bersangkutan.

* Trianggulasi (Gabungan).

Dalam teknik pengumpulan data, trianggulasi diartikan sebagai teknik pengumpulan data yang bersifat menggabungkan dari berbagai teknik pengumpulan data dan sumber data yang telah ada.

Dalam teknik pengumpulan data ini peneliti menggunakan cara :

$>$ Studi Pustaka.

Dasar-dasar ini diperoleh dari buku, literatur-literatur maupun tulisan-tulisan yang berhubungan dengan penelitian

$>$ Dokumentasi.

Metode pengumpulan data melalui dokumen yang sebenarnya dari kepustakaan ataupun dokumen yang sudah disimpan, untuk memperoleh informasi serta data yang dibutuhkan.

\section{d) Teknik Analisis Data}

Menurut Sujarweni (2015:121), analisis data diartikan sebagai upaya data yang sudah tersedia kemudian diolah dengan statistik dan dapat digunakan untuk menjawab rumusan masalah dalam penelitian. Dengan demikian, teknik analisis data, dengan tujuan mengolah data tersebut untuk menjawab rumusan masalah.

Untuk memecahkan masalah diatas penulis menggunakan alat bantu untuk mencari keterkaitan antara variabel - variabel memakai software SPSS versi 22.0 For Windows.

\section{a) Uji Asumsi Klasik}

Uji melihat layak atau tidaknya model regresi yang digunakan untuk memprediksi variabel terikat berdasarkan masukan variabel bebasnya, maka model regresi harus terbebas dari beberapa asumsi, antara lain : 


\section{$>\quad$ Uji Normalitas}

Uji Normalitas bertujuan untuk mengetahui distribusi data dalam variabel yang akan digunakan dalam penelitian (Sujarweni, 2014:52). Data yang baik dan layak digunakan dalam penelitian adalah data yang memiliki distribusi normal. Pengujian normalitas dalam penelitian ini dengan menggunakan one sample kolmogorovsmirnov test. Dalam uji one sample kolmogorov-smirnov test variabel - variabel yang mempunyai asymp. Sig (2-tailed) dibawah tingkat signifikan sebesar 0,05 maka diartikan bahwa variabel - variabel tersebut memiliki distribusi tidak normal dan sebaliknya. Pengambilan keputusan normal atau tidaknya data adalah sebagai berikut :

- Jika Sig $>0,05$ maka data berdistribusi normal

- Jika Sig $<0,05$ maka data tidak berdistribusi normal

\section{$>\quad$ Uii Multikolinearitas}

Uji Multikolinearitas diperlukan untuk mengetahui ada tidaknya variabel independent yang memiliki kemiripan antar variabel independent dalam satu model (Sujarweni, 2014:185). Untuk mendeteksi ada tidaknya multikolinearitas dalam model regresi dilakukan dengan melihat nilai tolerance dan nilai Variance Inflation Factor (VIF) yang dapat dilihat dari output SPSS. Sebagai dasar acuannya dapat disimpulkan:

1. Jika nilai tolerance $>10 \%$ dan nilai VIF $<10$, maka dapat disimpulkan bahwa tidak ada multikolineritas antar variabel bebas dalam model regresi.

2. Jika nilai tolerance $<10 \%$ dan nilai VIF $>10$, maka dapat disimpulkan bahwa ada multikolineritas antar variabel bebas dalam model regresi.

\section{$>\quad$ Uji Autokorelasi}

Menguji autokorelasi dalam suatu model bertujuan untuk mengetahui ada tidaknya korelasi antara variabel pengganggu pada periode tertentu dengan variabel sebelumnya (Sujarweni, 2015:186). Untuk mendeteksi autokorelasi dapat dilakukan dengan uji Durbin Watson (DW) dengan ketentuan menurut Sunyoto (2011:91). Sebagai berikut:

1. Terjadi autokorelasi positif jika nilai DW dibawah $-2(D W<-2)$

2. Tidak terjadi autokorelasi jika nilai DW berada diantara -2 dan +2 atau $-2 \leq$ $\mathrm{DW} \leq+2$

3. Terjadi autokorelasi negatif jika nilai DW diatas +2 atau DW $>+2$

$>\quad \underline{\text { Uji Heteroskesdastisitas }}$

Uji Heteroskesdastisitas menguji terjadinya perbedaan Variance resiual suatu periode pengamat ke periiode pengamat yang lain (Sujarweni, 2014:186). Menurut Priyatno (2014:108) cara memprediksi ada tidaknya heteroskesdastisitas pada suatu model dapat diuji dengan menggunakan teknik koefisien korelasi spearman's rho, yaitu mengkorelasikan variabel independent dengan residualnya. Pengujian menggunakan tingkat signifikan 0,05 dengan uji 2 sisi. Jika korelasi antar variabel independent dengan residual didapat P. Value maka dapat dikatakan bahwa tidak terjadi masalah heteroskesdastisitas.

\section{b) Uji Hipotesis}

$>$ Pengujian pengaruh Parsial (Uji t)

Uji statistik $\mathrm{t}$ pada dasarnya menunjukan seberapa jauh satu variabel penjelas/independen secara individual dalam menerangkan variasi variabel dependen (Ghozali, 2011:98). Uji t dilakukan dengan dengan derajat 
kepercayaan 5\%. Jika nilai signifikansi lebih kecil dari 5\% atau 0,05 maka variabel independen berpengaruh signifikan terhadap variabel dependen. Jika nilai signifikansi lebih besar dari $5 \%$ atau 0,05 maka terjadi hal yang sebaliknya.

$>\quad$ Pengujian pengaruh Simultan (Uji F)

Uji statistik pada dasarnya menunjukan apakah semua variabel bebas yang dimasukan dalam model mempunyai pengaruh secara bersama-sama terhadap variabel dependen (Ghozali, 2011:98). Cara yang digunakan adalah dengan tingkat kepercayaan 5\%. Jika nilai signifikansi lebih kecil dari 5\% atau 0,05 maka variabel independen berpengaruh signifikan secara bersama-sama. Namun jika nilai signifikansi lebih besar dari 5\% atau 0,05 maka terjadi hal yang sebaliknya.

\section{HASIL PENELITIAN}

\section{1) Deskripsi Data}

Data yang digunakan dalam penelitian ini adalah data sekunder. Data sekunder merupakan data yang diperoleh secara tidak langsung oleh peneliti dari perusahaan tetapi didapatkan dari pihak kedua, ketiga dan seterusnya. Objek dalam penelitian ini adalah Struktur Modal sebagai variabel dependen dan Risiko Bisnis, Non-Debt Tax Shield dan Profitabilitas sebagai variabel independen. Pengamatan yang dilakukan dengan menggunakan data time series sebanyak 60 bulan pengamatan selama 5 tahun dari tahun 2011-2016. Jumlah perusahaan yang terdaftar pada Perusahaan Perkebunan di Bursa Efek Indonesia hingga Desember 2016 adalah 16 perusahaan dan yang memenuhi kriteria untuk dianalisis sebanyak 10 perusahaan yaitu PT Astra Agro Lestari Tbk. (AALI), PT PP London Sumatra Indonesia Tbk. (LSIP), PT Eagle High Plantation Tbk. (BWPT), PT Sinar Mas Agro Tbk. (SMAR), PT Tunas Baru Lampung Tbk. (TBLA), PT Gozco Plantation Tbk. (GZCO), PT Jaya Agra Wattir Tbk. (JAWA), PT Salim Ivomas Pratama Tbk. (SIMP), PT Sampoerna Agro Tbk. (SGRO), PT Bakrie Sumatera Tbk. (UNSP).

Berikut ini adalah data Risiko Bisnis, Non-Debt Tax Shield, Profitabilitas dan Struktur Modal perusahaan sektor perkebunan selama 5 tahun dari tahun 20112016:

Tabel Tingkat Risiko Bisnis Pada Tahun 2011-2016 (dalam persentase)

\begin{tabular}{|c|c|c|c|c|c|c|}
\hline PERUSAHAAN & $\mathbf{2 0 1 1}$ & $\mathbf{2 0 1 2}$ & $\mathbf{2 0 1 3}$ & $\mathbf{2 0 1 4}$ & $\mathbf{2 0 1 5}$ & $\mathbf{2 0 1 6}$ \\
\hline AALI & 0.33 & 0.28 & 0.17 & 0.20 & 0.5 & 0.9 \\
LSIP & 0.31 & 0.19 & 0.13 & 0.14 & 0.9 & 0.8 \\
BWPT & 0.12 & 0.7 & 0.4 & 0.4 & 0.1 & 0.2 \\
SMAR & 0.16 & 0.18 & 0.1 & 0.1 & -0.1 & 0.5 \\
TBLA & 0.13 & 0.6 & -0.3 & 0.21 & 0.1 & 0.6 \\
GZCO & 0.6 & 0.4 & -0.8 & 0.60 & -0.1 & -0.4 \\
JAWA & 0.13 & 0.9 & 0.4 & 0.2 & 0 & -0.7 \\
SIMP & 0.11 & 0.8 & 0.3 & 0.5 & 0.2 & 0.2 \\
SGRO & 0.22 & 0.11 & 0.4 & 0.6 & 0.5 & 0.3 \\
UNSP & 0.5 & -0.5 & -0.17 & -0.3 & -0.9 & 0.2 \\
\hline TERTINGGI & 0.33 & 0.28 & 0.17 & 0.60 & 0.9 & 0.9 \\
TERENDAH & 0.5 & -0.5 & -0.17 & -0.3 & -0.9 & -0.7 \\
RATA-RATA & 0.16 & 0.10 & 0.2 & 0.12 & 0.1 & 0.2 \\
\hline
\end{tabular}

Berdasarkan tabel tersebut diketahui bahwa pada tahun 2011 tingkat risiko bisnis tertinggi yaitu sebesar 0.33 , tingkat risiko bisnis terendah yaitu 0.5 dan rata- 
rata tingkat risiko bisnis adalah sebesar 0.16 . Selanjutnya tahun 2012 tingkat risiko bisnis tertinggi yaitu 0.28 , tingkat risiko bisnis terendah yaitu -0.5 dan rata-rata tingkat risiko bisnis adalah sebesar 0.10. Pada tahun 2013 tingkat risiko bisnis tertinggi yaitu 0.17 , tingkat risiko terendah yaitu -0.17 dan rata-rata tingkat risiko bisnis adalah sebesar 0.2. Pada tahun 2014 tingkat risiko bisnis tertinggi yaitu 0.60, tingkat risiko terendah yaitu -0.3 dan rata-rata tingkat risiko bisnis adalah sebesar 0.12. Pada tahun 2015 tingkat risiko bisnis tertinggi yaitu 0.9, tingkat risiko terendah yaitu -0.9 dan rata-rata tingkat risiko bisnis adalah sebesar 0.1 . Sedangkan pada tahun 2016 tingkat risiko bisnis tertinggi yaitu 0.9, tingkat risiko terendah yaitu -0.7 dan rata-rata tingkat risiko bisnis adalah sebesar 0.2 .

Tabel Tingkat Non-Debt Tax Shield Pada Tahun 2011-2016 (dalam persentase)

\begin{tabular}{|c|c|c|c|c|c|c|}
\hline PERUSAHAAN & $\mathbf{2 0 1 1}$ & $\mathbf{2 0 1 2}$ & $\mathbf{2 0 1 3}$ & $\mathbf{2 0 1 4}$ & $\mathbf{2 0 1 5}$ & $\mathbf{2 0 1 6}$ \\
\hline AALI & 0.35 & 0.32 & 0.35 & 0.37 & 0.43 & 0.46 \\
LSIP & 0.27 & 0.30 & 0.48 & 0.51 & 0.55 & 0.47 \\
BWPT & 0.13 & 0.14 & 0.3 & 0.6 & 0.22 & 0.25 \\
SMAR & 0.43 & 0.48 & 0.55 & 0.55 & 0.59 & 0.58 \\
TBLA & 0.45 & 0.43 & 0.24 & 0.27 & 0.60 & 0.68 \\
GZCO & 0.14 & 0.18 & 0.10 & 0.30 & 0.16 & 0.09 \\
JAWA & 0.14 & 0.19 & 0.26 & 0.31 & 0.34 & 0.35 \\
SIMP & 0.31 & 0.32 & 0.38 & 0.40 & 0.46 & 0.48 \\
SGRO & 0.31 & 0.36 & 0.43 & 0.39 & 0.26 & 0.31 \\
UNSP & 0.5 & 0.5 & 0.49 & 0.16 & 0.39 & 0.19 \\
\hline TERTINGGI & 0.45 & 0.48 & 0.55 & 0.55 & 0.60 & 0.68 \\
TERENDAH & 0.5 & 0.5 & 0.3 & 0.6 & 0.16 & 0.9 \\
RATA-RATA & 0.26 & 0.5 & 0.49 & 0.33 & 0.40 & 0.39 \\
\hline
\end{tabular}

Berdasarkan tabel tersebut diketahui bahwa pada tahun 2011 tingkat risiko bisnis tertinggi yaitu sebesar 0.45 , tingkat risiko bisnis terendah yaitu 0.5 dan ratarata tingkat risiko bisnis adalah sebesar 0.26 . Selanjutnya tahun 2012 tingkat risiko bisnis tertinggi yaitu 0.48 , tingkat risiko bisnis terendah yaitu 0.5 dan rata-rata tingkat risiko bisnis adalah sebesar 0.5. Pada tahun 2013 tingkat risiko bisnis tertinggi yaitu 0.55, tingkat risiko terendah yaitu 0.3 dan rata-rata tingkat risiko bisnis adalah sebesar 0.49. Pada tahun 2014 tingkat risiko bisnis tertinggi yaitu 0.55, tingkat risiko terendah yaitu 0.6 dan rata-rata tingkat risiko bisnis adalah sebesar 0.33. Pada tahun 2015 tingkat risiko bisnis tertinggi yaitu 0.60, tingkat risiko terendah yaitu 0.16 dan rata-rata tingkat risiko bisnis adalah sebesar 0.40 . Sedangkan pada tahun 2016 tingkat risiko bisnis tertinggi yaitu 0.68 , tingkat risiko terendah yaitu 0.9 dan rata-rata tingkat risiko bisnis adalah sebesar 0.39 .

Tabel Tingkat Profitabilitas Pada Tahun 2011-2016 (dalam persentase)

\begin{tabular}{|c|c|c|c|c|c|c|}
\hline PERUSAHAAN & $\mathbf{2 0 1 1}$ & $\mathbf{2 0 1 2}$ & $\mathbf{2 0 1 3}$ & $\mathbf{2 0 1 4}$ & $\mathbf{2 0 1 5}$ & $\mathbf{2 0 1 6}$ \\
\hline AALI & 0.2 & 0.20 & 0.13 & 0.1 & 0.3 & 0.9 \\
LSIP & 0.3 & 0.15 & 0.10 & 0.11 & 0.7 & 0.6 \\
BWPT & 0.03 & 0.2 & 0.1 & 0.1 & -0.1 & -0.2 \\
SMAR & 0.12 & 0.13 & 0.5 & 0.7 & -0.2 & 0.10 \\
TBLA & 0.10 & 0.05 & 0.8 & 0.9 & 0.3 & 0.1 \\
GZCO & 0.5 & 0.3 & -0.08 & 0.6 & -0.1 & -0.4 \\
JAWA & 0.10 & 0.07 & 0.3 & 0.2 & -0.5 & -0.7
\end{tabular}




\begin{tabular}{|c|c|c|c|c|c|c|} 
SIMP & 0.10 & 0.6 & 0.2 & 0.4 & 0.1 & 0.2 \\
SGRO & 0.16 & 0.8 & 0.3 & 0.6 & 0.4 & 0.6 \\
UNSP & 0.3 & -0.5 & -0.1 & -0.3 & -0.7 & -0.4 \\
\hline TERTINGGI & 0.16 & 0.20 & 0.13 & 0.11 & 0.7 & 0.10 \\
TERENDAH & 0.3 & -0.5 & -0.8 & -0.3 & 0.1 & -0.7 \\
RATA-RATA & 0.7 & 0.7 & 0.3 & 0.4 & 0 & 0.1 \\
\hline
\end{tabular}

Berdasarkan tabel tersebut diketahui bahwa pada tahun 2011 tingkat risiko bisnis tertinggi yaitu sebesar 0.16 , tingkat risiko bisnis terendah yaitu 0.3 dan ratarata tingkat risiko bisnis adalah sebesar 0.7. Selanjutnya tahun 2012 tingkat risiko bisnis tertinggi yaitu 0.20 , tingkat risiko bisnis terendah yaitu -0.5 dan rata-rata tingkat risiko bisnis adalah sebesar 0.7. Pada tahun 2013 tingkat risiko bisnis tertinggi yaitu 0.13 , tingkat risiko terendah yaitu -0.8 dan rata-rata tingkat risiko bisnis adalah sebesar 0.3. Pada tahun 2014 tingkat risiko bisnis tertinggi yaitu 0.13 , tingkat risiko terendah yaitu 0.1 dan rata-rata tingkat risiko bisnis adalah sebesar -0.3 . Pada tahun 2015 tingkat risiko bisnis tertinggi yaitu 0.7 , tingkat risiko terendah yaitu 0.1 dan rata-rata tingkat risiko bisnis adalah sebesar 0.0. Sedangkan pada tahun 2016 tingkat risiko bisnis tertinggi yaitu 0.10 , tingkat risiko terendah yaitu -0.7 dan rata-rata tingkat risiko bisnis adalah sebesar 0.1 .

Tabel Tingkat Struktur Modal Pada Tahun 2011-2016 (dalam persentase)

\begin{tabular}{|c|c|c|c|c|c|c|}
\hline PERUSAHAAN & $\mathbf{2 0 1 1}$ & $\mathbf{2 0 1 2}$ & $\mathbf{2 0 1 3}$ & $\mathbf{2 0 1 4}$ & $\mathbf{2 0 1 5}$ & $\mathbf{2 0 1 6}$ \\
\hline AALI & 0.21 & 0.33 & 0.46 & 0.57 & 0.84 & 0.38 \\
LSIP & 0.16 & 0.20 & 0.21 & 0.20 & 0.21 & 0.24 \\
BWPT & 1.52 & 1.95 & 1.84 & 0.41 & 1.64 & 1.60 \\
SMAR & 1.01 & 0.82 & 1.11 & 1.10 & 1.47 & 1.20 \\
TBLA & 1.64 & 1.95 & 0.79 & 0.46 & 0.49 & 0.67 \\
GZCO & 0.83 & 1.05 & 1.13 & 1.08 & 0.86 & 2.10 \\
JAWA & 0.71 & 0.79 & 1.09 & 1.33 & 1.61 & 2.13 \\
SIMP & 0.68 & 0.65 & 0.74 & 0.88 & 0.84 & 0.85 \\
SGRO & 0.36 & 0.55 & 0.67 & 0.81 & 1.13 & 1.22 \\
UNSP & 1.06 & 1.40 & 2.70 & 3.20 & 1.17 & 1.21 \\
\hline TERTINGGI & 1.64 & 1.95 & 2.70 & 3.20 & 1.64 & 2.13 \\
TERENDAH & 0.16 & 0.20 & 0.21 & 0.20 & 0.21 & 0.24 \\
RATA-RATA & 0.82 & 0.97 & 1.07 & 1.00 & 1.03 & 1.16 \\
\hline
\end{tabular}

\section{2) Statistik Deskriptif}

Statistik deskriptif merupakan proses pengumpulan, penyajian, dan peringkasan berbagai karakteristik data dalam upaya untuk menggambarkan data tersebut secara memadai. Statistik deskriptif digunakan untuk mengambil data dengan cara mendeskripsikan atau menggambarkan data yang terkumpul tanpa bermaksud membuat kesimpulan yang berlaku untuk umum atau generalisasi. Analisis deskriptif dalam penelitian ini untuk mengetahui gambaran data secara statistik dari Risiko Bisnis, Non-Debt Tax Shield, Profitabilitas dan Struktur Modal yang akan diteliti. 
Berikut ini akan disajikan analisis statistik deskriptif dalam penelitian ini:

Tabel Deskripsi Variabel Penelitian Descriptive Statistics

\begin{tabular}{|l|r|r|r|r|r|}
\hline & N & Minimum & Maximum & Mean & $\begin{array}{c}\text { Std. } \\
\text { Deviation }\end{array}$ \\
\hline Risiko Bisnis & 60 & -.17 & .60 & .0752 & .11734 \\
Non-Debt Tax Shield & 60 & .03 & .68 & .3295 & .16087 \\
Profitabilitas & 60 & -.14 & .25 & .0485 & .07406 \\
Struktur Modal & 60 & .16 & 3.20 & 1.0085 & .63001 \\
Valid N (listwise) & 60 & & & & \\
\hline
\end{tabular}

Pada tabel diatas menunjukkan bahwa jumlah data yang digunakan dalam penelitian ini sebanyak 60 sampel data yang diambil dari Laporan keuangan publikasi perusahaan sektor perkebunan periode 2011-2016

* Risiko Bisnis

Berdasarkan hasil pengujian tersebut diketahui bahwa tingkat risiko bisnis terendah yaitu -0.17 dan tertinggi 0.60 . Hasil tersebut menunjukkan bahwa besarnya tingkat risiko bisnis yang menjadi sampel penelitian ini berkisar antara -0.17 sampai 0.60 dengan nilai mean 0.0752 pada standar deviasi 0.117345

\section{* Non-Debt Tax Shield}

Berdasarkan hasil pengujian tersebut diketahui bahwa tingkat non-debt tax shield terendah yaitu 0.03 dan tertinggi 0.68 . Hasil tersebut menunjukkan bahwa besarnya tingkat non-debt tax shield yang menjadi sampel penelitian ini berkisar antara 0.03 sampai 0.68 dengan nilai mean 0.3295 pada standar deviasi 0.16087 .

\section{* Profitabilitas}

Berdasarkan hasil pengujian tersebut diketahui bahwa tingkat Inflasi terendah yaitu -0.14 dan tertinggi 0.25 Hasil tersebut menunjukkan bahwa besarnya tingkat Inflasi yang menjadi sampel penelitian ini berkisar antara -0.14 sampai 0.25 dengan nilai mean 0.0485 pada standar deviasi 0.07406

\section{* Struktur Modal}

Berdasarkan hasil pengujian tersebut diketahui bahwa indeks harga saham terendah yaitu 0.16 dan tertinggi 3.20 Hasil tersebut menunjukkan bahwa besarnya indeks harga saham yang menjadi sampel penelitian ini berkisar antara 0.16 sampai 3.20 dengan nilai mean 1.0085 pada standar deviasi 0.63001

\section{3) Pengujian Asumsi Klasik}

Pengujian asumsi klasik diperlukan untuk mengetahui apakah hasil estimasi regresi yang dilakukan benar-benar bebas dari adanya gejala heteroskedastisitas, gejala multikolinearitas, dan gejala autokorelasi. Model regresi akan dijadikan alat estimasi yang tidak bias jika telah memenuhi persyaratan BLUE (best linear unbiased estimator) yakni tidak terdapat heteroskedastistas, tidak terdapat multikolinearitas, dan tidak terdapat autokorelasi.

Sebelum dilakukan pengujian regresi linier berganda terhadap hipotesis penelitian, maka terlebih dahulu perlu dilakukan suatu pengujian untuk mengetahui 
ada tidaknya pelanggaran terhadap asumsi-asumsi klasik. Hasil pengujian hipotesis yang baik adalah pengujian yang tidak melanggar asumsi-asumsi klasik yang mendasari model regrasi linier berganda. Asumsi-asumsi klasik dalam penelitian ini meliputi uji normalisasi, uji multikolinieritas, uji heteroskedastisitas dan uji autokorelasi.

\section{a) Uji Normalitas}

Pengujian normalitas dilakukan dengan maksud untuk melihat distribusi normal atau tidaknya data yang dianalisis. Pengujian ini untuk melihat apakah dalam model regresi, variabel pengganggu atau residual memiliki distribusi normal. Salah satu cara untuk mendeteksi nilai residual normal atau tidak dengan menggunakan uji Kolmogorov Smirnov (Uji K-S). Hipotesis yang digunakan adalah data residual tidak berdistribusi normal $(\mathrm{HO})$ dan data residual berdistribusi normal $(\mathrm{Ha})$.

Data penelitian dikatakan menyebar normal atau memenuhi uji nprmalitas apabila nilai Asymp.sig (2-tailed) variabel residual berada di atas 0.05 Sebaliknya, apabila nilai Asymp.Sig (2-tailed) variabel residual berada di bawah 0.05, maka data tersebut tidak berdistribusi normal atau data tidak memenuhi uji normalitas (Ghozali, 2011: 160-165)..

Hasil Uji Normalitas dalam penelitian ini dapat dilihat pada tabel berikut ini :

Tabel Hasil Uji Normalitas

One-Sample Kolmogorov-Smirnov Test

\begin{tabular}{|ll|r|r|r|r|}
\hline & & \multicolumn{1}{c|}{$\begin{array}{c}\text { Risiko } \\
\text { Bisnis }\end{array}$} & $\begin{array}{c}\text { Non-Debt } \\
\text { Tax Shield }\end{array}$ & Profitabilitas & \multicolumn{1}{c|}{$\begin{array}{c}\text { Struktur } \\
\text { Modal }\end{array}$} \\
\hline $\mathrm{N}$ & Mean & 60 & 60 & 60 & 60 \\
\multirow{2}{*}{ Normal Parameters } & Std. & .0768 & .3295 & .0485 & 1.0085 \\
& Deviation & .11432 & .16087 & .07406 & .63001 \\
Most Extreme & Absolute & .154 & .084 & .085 & .119 \\
Differences & Positive & .154 & .064 & .077 & .119 \\
Kolmogorov-Smirnov Z & Negative & -.079 & -.084 & -.085 & -.089 \\
Asymp. Sig. (2-tailed) & 1.194 & .650 & .658 & .918 \\
\hline
\end{tabular}

a. Test distribution is Normal.

b. Calculated from data.

Hasil analisis residual pada tabel di atas menyatakan bahwa nilai signifikansi dari fungsi regresi variabel tingkat risiko bisnis, non-debt tax shield, profitabilitas dan struktur modal adalah sebesar $0.115,0,792,0.780$ dan 0.368 Nilai tersebut lebih besar dari $0.05 \mathrm{Hal}$ ini dapat disimpulkan bahwa fungsi regresi dari keempat variabel tersebut telah berdistribusi normal.

\section{b) Uji Multikolinearitas}

Uji ini bertujuan untuk menguji apakah dalam model regresi ditemukan adanya kolerasi antara variabel independent. Model yang baik seharusnya tidak terjadi kolerasi antara variabel bebas. Multikolinearitas dapat dilihat dari nilai tolerance dan Variance Inflation Factor (VIF). Tolerance mengukur variabilitas variabel independen yang terpilih yang tidak dijelaskan oleh variabel independen lainnya, sehingga nilai tolerance yang rendah sama dengan nilai VIF tinggi, karena VIF $=1 /$ tolerance. Data 
dikatakan bebas dari masalah multikolinearitas apabila memiliki nilai tolerance $\geq 0.10$ atau sama dengan nilai VIF $\leq 0.10$ (Ghozali, 2011: 105-106).

Ringkasan hasil Uji Multikolinearitas disajikan pada tabel berikut:

\section{Tabel Hasil Uji Multikolinearitas} Coefficients $^{\mathrm{a}}$

\begin{tabular}{|l|r|r|}
\hline \multirow{2}{*}{ Model } & \multicolumn{2}{|c|}{ Collinearity Statistics } \\
\cline { 2 - 3 } & \multicolumn{1}{|c|}{ Tolerance } & \multicolumn{1}{c|}{ VIF } \\
\hline \multicolumn{1}{|c|}{ (Constant) } & .435 & 2.299 \\
Risiko Bisnis & .985 & 1.015 \\
Non-Debt Tax Shield & .431 & 2.321 \\
\hline
\end{tabular}

a. Dependent Variable: Struktur Modal

Berdasarkan tabel di atas hasil perhitungan nilai tolerance menunjukkan bahwa tidak ada variable independen yang mempunyai nilai tolerance $\leq 0.10$ dan tidak ada nilai $\mathrm{VIF} \geq 0.10$, sehingga dapat disimpulkan bahwa model regresi pada penelitian ini tidak terjadi multikolinearitas dan model regresi layak digunakan.

\section{c) Uji Autokorelasi}

Uji autokorelasi bertujuan untuk mengetahui apakah dalam model regresi linear ada korelasi antara kesalahan pengganggu pada periode $t$ dengan kesalahan pengganggu pada periode $\mathrm{t}-1$. Apabila terjadi korelasi maka ada autokorelasi. Autokorelasi muncul karena observasi yang berurutan sepanjang waktu berkaitan satu samalainnya. Beberapa cara yang dapat digunakan untuk mendeteksi ada atau tidaknya autokorelasi, salah satunya adalah dengan uji Durbin-Watson (Dw-test). Uji ini menggunakan tehnik regresi dengan melihat nilai Durbin-Watson (DW-test) (Ghozali, 2011:110-111).

Hasil uji autokorelasi dalam penelitian inidapat dilihat pada tabel berikut ini :

Tabel Hasil Uji Autokorelasi Model Summary ${ }^{b}$

\begin{tabular}{|l|r|r|r|r|r|}
\hline Model & \multicolumn{1}{|c|}{$\mathrm{R}$} & $\mathrm{R}$ Square & $\begin{array}{c}\text { Adjusted R } \\
\text { Square }\end{array}$ & $\begin{array}{c}\text { Std. Error of } \\
\text { the Estimate }\end{array}$ & Durbin-Watson \\
\hline 1 & $.592^{\mathrm{a}}$ & .351 & .316 & .52105 & 1.936 \\
\hline
\end{tabular}

a. Predictors: (Constant), Profitabilitas, Non-Debt Tax Shield, Risiko Bisnis

b. Dependent Variable: Struktur Modal

Berdasarkan hasil hitung menunjukkan nilai Durbin Watson sebesar 1.936. Karena angka D-W berada diantara -2 sampai +2 , hal ini berarti tidak terdapat masalah autokorelasi. Jadi dapat disimpulkan dalam model regresi tidak ada korelasi antara kesalahan pengganggu pada periode t dengan kesalahan pengganggu pada periode $\mathrm{t}-1$.

\section{d) Uji Heteroskedastisitas}

Salah satu cara untuk melihat ada tidaknya heterokedaskitas adalah menggunakan Uji Glejser. Metode uji heterokedastisitas dengan kolerasi Uji Glejser yaitu mengkorelasikan variabel independen dengan nilai unstandardised residual. 
Kretaria yang biasa digunakan untuk menyatakan apakah terjadi heterokedastisitas atau tidak diantara data pengamatan dapat dijelaskan dengan menggunakan koefisien signifikansi harus dibandingkan dengan tingkat signifikansi yang ditetapkan sebelumnya $(\mathrm{a}=5 \%$ ). Apabila koefisien signifikansi (nilai probabilitas) lebih besar dari tingkat signifikansi yang ditetapkan, maka dapat disimpulkan tidak terjadi heteroskedastisitas (Ghozali, 2011: 142-143).

Hasil pengujian dapat dilihat di tabel berikut :

Tabel Hasil Uji Heteroskedastisitas

Coefficients $^{a}$

\begin{tabular}{|c|c|c|c|c|c|c|}
\hline \multirow{2}{*}{\multicolumn{2}{|c|}{ Model }} & \multicolumn{2}{|c|}{$\begin{array}{l}\text { Unstandardized } \\
\text { Coefficients }\end{array}$} & $\begin{array}{c}\text { Standardized } \\
\text { Coefficients }\end{array}$ & \multirow[t]{2}{*}{$\bar{t}$} & \multirow[t]{2}{*}{ Sig. } \\
\hline & & $B$ & Std. Error & Beta & & \\
\hline \multirow{4}{*}{1} & (Constant) & 1.437 & .159 & & $\overline{9.047}$ & .000 \\
\hline & RisikoBisnis & -1.339 & .732 & -.243 & -1.831 & .072 \\
\hline & Non-Debt Tax Shield & -.476 & .430 & -.122 & -1.107 & .273 \\
\hline & Profitabilitas & -4.100 & 1.441 & -.384 & -2.846 & .006 \\
\hline
\end{tabular}

a. Dependent Variable: Struktur Modal

Dari output di atas dapat diketahui bahwa nilai korelasi ketiga variabel independen dengan Unstandardized Residual memiliki nilai signifikansi masing $(0.700,0.187$ dan 0.06$)$ lebih besar dari 0,05 . Karena signifikansi lebih besar dari 0.05 maka dapat disimpulkan bahwa tidak terjadi masalah heteroskedastisitas pada model regresi.

\section{4) Analisis Data}

\section{a) Analisis Regresi Berganda}

Menurut Priyatno (2012), analisis regresi linier berganda adalah analisis untuk mengukur besarnya pengaruh antara dua tau lebih variable independen terhadap suatu variable dependen dan memprediksi variable dependen dengan menggunakan variable independen. Pada regresi berganda terdapat satu variable terikat dan lebih dari satu variabel bebas. Dalam penelitian ini yang menjadi variabel terikat adalah struktur modal, sedangkan yang menjadi variabel bebas adalah risiko bisnis, nondebt tax shield dan profitabilitas. Hasil pengujian regresi berganda dapat dilihat dalam tabel sebagai berikut :

\section{Tabel Hasil Uji Regresi Berganda}

Coefficients $^{\mathrm{a}}$

\begin{tabular}{|c|c|c|c|c|c|}
\hline \multirow[t]{2}{*}{ Model } & \multicolumn{2}{|c|}{$\begin{array}{c}\text { Unstandardized } \\
\text { Coefficients }\end{array}$} & $\begin{array}{l}\text { Standardized } \\
\text { Coefficients }\end{array}$ & \multirow[t]{2}{*}{$t$} & \multirow[t]{2}{*}{ Sig. } \\
\hline & $B$ & Std. Error & Beta & & \\
\hline (Constant) & 1.437 & .159 & & 9.047 & .000 \\
\hline RisikoBisnis & -1.339 & .732 & -.243 & -1.831 & .072 \\
\hline $\begin{array}{l}\text { Non-Debt Tax } \\
\text { Shield }\end{array}$ & -.476 & .430 & -.122 & -1.107 & .273 \\
\hline Profitabilitas & -4.100 & 1.441 & -.384 & -2.846 & .006 \\
\hline
\end{tabular}

a. Dependent Variable: Struktur Modal 
Berdasarkan hasil perhitungan regresi berganda, didapat persamaan sebagai berikut:

$$
Y=1,437-1,339 X_{1}-0,476 X_{2}-4,100 X_{3}+e
$$

Dari persamaan regresi linier berganda di atas didapatkan konstanta sebesar 1,437. Hal ini menunjukkan bahwa jika variabel-variabel independen diasumsikan dalam keadaan tetap, maka variabel dependen akan naik sebesar 1,437.

\section{b) Pengujian Hipotesis}

Pengujian hipotesis dalam penelitian ini harus dilakukan analisis statistik terlebih dahulu pada data yang telah diperoleh sebelumnya. Analisis statistik yang digunakan dalam penelitian ini adalah analisis regresi. Uji regresi khususnya Uji t dan uji $F$ sangat dipengaruhi oleh nilai residual yang mengikuti distribusi normal, sehingga apabila asumsi ini menyimpan dari distribusi normal akan menyebabkan uji statistic menjadi tidak valid. Oleh karena itu, jika terdapat data yang menyimpang dari penyebarannya, maka data tersebut tidak disertakan dalam analisis.

Hipotesis pertama, kedua, ketiga dan keempat pada penelitian ini akan diuji menggunakan uji parsial (uji t) untuk mengetahui apakah variabel bebas secara individual berpengaruh terhadap variabel terikat, Sedangkan uji F digunakan untuk mengetahui apakah variabel bebas secara bersama-sama berpengaruh terhadap variabel terikat.

\section{* Pengujian Secara Parsial (Uji t)}

Uji t bertujuan untuk menguji pengaruh masing-masing variable independen terhadap variable dependen. Hasil uji t dapat dilihat pada tabel dibawah ini

\section{Tabel Hasil Perhitungan Uji t}

Coefficients $^{\mathrm{a}}$

\begin{tabular}{|c|c|c|c|c|c|c|}
\hline \multirow{2}{*}{\multicolumn{2}{|c|}{ Model }} & \multicolumn{2}{|c|}{$\begin{array}{l}\text { Unstandardized } \\
\text { Coefficients }\end{array}$} & \multirow{2}{*}{$\begin{array}{c}\text { Standardized } \\
\text { Coefficients } \\
\text { Beta } \\
\end{array}$} & \multirow[t]{2}{*}{$\mathrm{t}$} & \multirow[t]{2}{*}{ Sig. } \\
\hline & & $B$ & Std. Error & & & \\
\hline \multirow{4}{*}{1} & (Constant) & 1.437 & .159 & & 9.047 & .000 \\
\hline & RisikoBisnis & -1.339 & .732 & -.243 & -1.831 & .072 \\
\hline & $\begin{array}{l}\text { Non-Debt Tax } \\
\text { Shield }\end{array}$ & -.476 & .430 & -.122 & -1.107 & .273 \\
\hline & Profitabilitas & -4.100 & 1.441 & -.384 & -2.846 & .006 \\
\hline
\end{tabular}

a. Dependent Variable: Struktur Modal

Hasil pengujian hipotesis masing-masing variable independen secara parsial terhadap variable dependennya dapat dianalisis sebagai berikut :

1) Pengaruh Variabel Risiko Bisnis Terhadap Struktur Modal.

Hipotesis ini digunakan untuk menguji kebenaran bahwa tingkat risiko bisnis berpengaruh signifikan terhadap struktur modal pada perusahaan sektor perkebunan periode tahun 2011-2016.

Dengan tingkat kepercayaan $5 \%$ atau a $=0,05$, Ha diterima bila nilai signifikansi atau probabilitas lebih kecil dari 0,05 dan Ha ditolak bila nilai signifikansi lebih besar dari 0,05 . 
Hipotesis 1 menyatakan bahwa risiko bisnis berpengaruh secara negatif terhadap struktur modal. Pada hasil output SPSS menunjukkan nilai koefisien risiko bisnis sebesar -1,139 dan nilai signifikansi sebesar 0,72 lebih besar dari tingkat signifikansi $5 \%$ atau 0,05 , dengan demikian $\mathrm{H}_{a}$ ditolak. Hal tersebut menunjukkan bahwa risiko bisnis (X1) tidak berpengaruh terhadap struktur modal, sehingga hipotesis 1 ditolak.

2) Pengaruh Variabel Non-Debt Tax Shield Terhadap Struktur Modal.

Hipotesis ini digunakan untuk menguji kebenaran bahwa tingkat risiko bisnis berpengaruh signifikan terhadap struktur modal pada perusahaan sektor perkebunan periode tahun 2011-2016.

Dengan tingkat kepercayaan $5 \%$ atau a $=0,05$, Ha diterima bila nilai signifikansi atau probabilitas lebih kecil dari 0,05 dan Ha ditolak bila nilai signifikansi lebih besar dari 0,05 .

Hipotesis 2 menyatakan bahwa risiko bisnis berpengaruh secara negatif terhadap struktur modal. Pada hasil output SPSS menunjukkan nilai koefisien nondebt tax shield sebesar -0,476 dan nilai signifikansi sebesar 0,273 lebih besar dari tingkat signifikansi 5\% atau 0,05, dengan demikian $\mathrm{H}_{a}$ ditolak. Hal tersebut menunjukkan bahwa non-debt tax shield (X2) tidak berpengaruh terhadap struktur modal, sehingga hipotesis 2 ditolak.

3) Pengaruh Variabel Profitabilitas Terhadap Struktur Modal.

Hipotesis ini digunakan untuk menguji kebenaran bahwa tingkat risiko bisnis berpengaruh signifikan terhadap struktur modal pada perusahaan sektor perkebunan periode tahun 2011-2016.

Dengan tingkat kepercayaan $5 \%$ atau a $=0,05$, Ha diterima bila nilai signifikansi atau probabilitas lebih kecil dari 0,05 dan $\mathrm{Ha}$ ditolak bila nilai signifikansi lebih besar dari 0,05 .

Hipotesis 3 menyatakan bahwa risiko bisnis berpengaruh secara negatif terhadap struktur modal. Pada hasil output SPSS menunjukkan nilai koefisien profitabilitas sebesar $-4,100$ dan nilai signifikansi sebesar 0,06 lebih besar dari tingkat signifikansi $5 \%$ atau 0,05 , dengan demikian $\mathrm{H}_{\mathrm{a}}$ ditolak. Hal tersebut menunjukkan bahwa profitabilitas (X3) tidak berpengaruh terhadap struktur modal, sehingga hipotesis 3 ditolak.

\section{* Pengujian secara simultan (Uji F)}

Uji $F$ digunakan untuk mengetahui apakah secara bersama-sama (simultan) variable independen berpengaruh signifikan terhadap variable dependen. Hasil pengujian uji F dapat dilihat pada tabel

Tabel Hasil Perhitungan Uji F ANOVA $^{\mathrm{a}}$

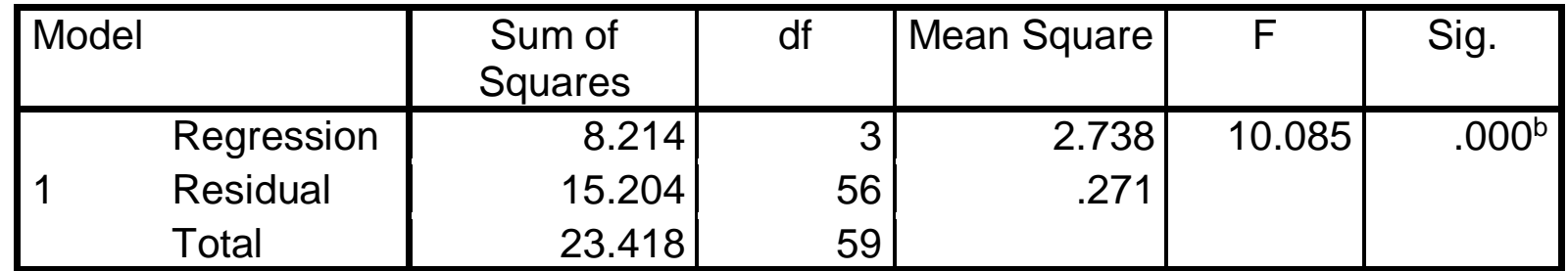

a. Dependent Variable: Struktur Modal

b. Predictors: (Constant), Profitabilitas, Non-Debt Tax Shield, Risiko Bisnis 
Berdasarkan hasil uji statistik F pada tabel diatas mempunyai nilai signifikansi 0,000 . Hal ini berarti tingkat nilai signifikansi berada di bawah signifikansi $5 \%$ atau lebih kecil dari 0,05, yang artinya disimpulkan bahwa risiko bisnis, non-debt tax shield dan profitabilitas secara bersama-sama (simultan) signifikan berpengaruh terhadap struktur modal.

\section{E. PEMBAHASAN}

1. Pengaruh Risiko Bisnis, Non-Debt Tax Shield dan Profitabilitas terhadap Struktur Modal Perusahaan Sektor Perkebunan di Bursa Efek Indonesia

Berdasarkan tabel 4.12 penelitian ini memperoleh hasil bahwa secara statistik ada pengaruh yang signifikan antara X1 (risiko bisnis), X2 (non-debt tax shield), X3 (profitabilitas) terhadap struktur modal. Berdasarkan hasil perhitungan pada pengujian $\mathrm{F}$ dengan tingkat signifikansi $5 \%$ didapat nilai signifikansi 0,000 yang lebih kecil dari 0,05 dengan demikian hipotesis diterima. Hal ini memberikan gambaran bahwa dengan risiko bisnis, non-debt tax shield dan profitabilitas yang tinggi, maka akan semakin tinggi pula struktur modal pada perusahaan perkebunan.

\section{Pengaruh Risiko Bisnis terhadap Struktur Modal Perusahaan Sektor Perkebunan di Bursa Efek Indonesia}

Berdasarkan hasil penelitian diperoleh hasil bahwa secara statistik tidak ada pengaruh negatif antara risiko bisnis terhadap struktur modal. Nilai koefisien risiko bisnis sebesar -1,139 kemudian nilai signifikansi sebesar 0,72 yang lebih besar dari 0,05 dengan demikian hipotesis 1 ditolak. Artinya pada periode penelitian tahun 2011-2016 tidak ditemukan adanya pengaruh antara risiko bisnis (X1) terhadap struktur modal $(Y)$. Hal ini menggambarkan bahwa besar kecilnya risiko bisnis pada perusahaan perkebunan tidak mempengaruhi terhadap besar kecilnya suatu kebijakan struktur modal perusahaan yang akan di ambil perusahaan.

\section{Pengaruh Non-Debt Tax Shield terhadap Struktur Modal Perusahaan Sektor Perkebunan di Bursa Efek Indonesia}

Berdasarkan hasil penelitian diperoleh hasil bahwa secara statistik tidak ada pengaruh negatif dan signifikan antara non-debt tax shield terhadap struktur modal. Nilai koefisien non-debt tax shield sebesar -.476 kemudian nilai signifikansi sebesar 0,273 yang lebih besar dari 0,05 dengan demikian hipotesis 2 ditolak. Artinya pada periode penelitian tahun 2011-2016 tidak ditemukan adanya pengaruh antara nondebt tax shield (X2) terhadap struktur modal (Y). Hal ini menggambarkan bahwa besar kecilnya non-debt tax shield pada perusahaan Perkebunan tidak mempengaruhi besar kecilnya suatu kebijakan struktur modal yang akan di ambil perusahaan.

\section{Pengaruh Profitabilitas terhadap Perusahaan Struktur Modal Perusahaan Sektor Perkebunan di Bursa Efek Indonesia}

Berdasarkan hasil penelitian diperoleh hasil bahwa secara statistik tidak ada pengaruh negatif dan signifikan antara profitabilitas terhadap struktur modal. Nilai koefisien profitabilitas sebesar -4.100 kemudian nilai signifikansi sebesar 0,06 yang lebih besar dari 0,05 dengan demikian hipotesis 3 ditolak. Artinya pada periode penelitian tahun 2011-2016 tidak ditemukan adanya pengaruh antara profitabilitas (X3) terhadap struktur modal (Y). Hal ini menggambarkan bahwa besar kecilnya 
profitabilitas pada perusahaan Perkebunan tidak mempengaruhi besar kecilnya suatu kebijakan struktur modal yang akan di ambil perusahaan.

\section{F. KESIMPULAN DAN SARAN}

1) Kesimpulan

Berdasarkan hasil analisa pembahasan yang telah dilakukan terhadap kedua hipotesis yang telah menggunakan regresi berganda diperoleh kesimpulan sebagai berikut :

a) Risiko bisnis, Non-Debt Tax Shield dan Profitabilitas secara simultan berpengaruh terhadap struktur modal pada perusahaan perkebunan periode tahun 2011 - 2016. Besarnya pengaruh risiko bisnis, non-debt tax shield, profitabilitas, terhadap struktur modal sebesar $31,6 \%$ terhadap variabel dependennya.

b) Risiko bisnis, On-Debt Tax Shield dan Profitabilitas secara parsial tidak berpengaruh signifikan terhadap struktur modal pada perusahaan perkebunan periode tahun 2011 - 2016. Artinya tinggi atau rendahnya risiko bisnis perusahaan perkebunan periode 2011 - 2016 tidak akan mempengaruhi kebijakan struktur modal yang akan diambil perusahaan.

\section{2) Saran}

Berdasarkan hasil penelitian yang telah dikemukakan, dapat diberikan saran sebagai berikut :

a) Bagi investor dan manajemen perusahaan perkebunan yang terdaftar di BEI hendaknya lebih memperhatikan pengambilan keputusan yang berkaitan dengan struktur modal perusahaan melalui analisis dan perhitungan komposisi struktur modal yang mendekati optimal sehingga memberikan nilai perusahaan yang maksimal dan biaya modal yang minimal. Peningkatan nilai perusahaan ini pada akhirnya akan meningkatkan kesejahteraan para pemegang saham.

b) Pada penelitian selanjutnya, diharapkan dapat menambah kajian lebih lanjut atau menambahkan variabel independen lainnya pada penelitian ini dengan variabel-variabel lain yang mempengaruhi struktur modal, dikarenakan variabel independen dalam penelitian ini hanya dapat menjelaskan sebanyak $24,2 \%$ terhadap variabel dependennya.

\section{DAFTAR PUSTAKA}

Brigham F Eugene \& Houston F Joel. 2006. Fundamental of Financial Management, Dasar-Dasar Manajemen Keuangan. Edisi 10 Jakarta :Salemba Empat.

Ghozali, Imam. 2011. Aplikasi Analisis Multivariate dengan Program SPSS. Semarang : Badan Penerbit Fakultas Ekonomi Universitas Diponegoro.

Mardinawati. 2010. Analisis Faktor-Faktor Yang Mempengaruhi Struktur Modal Pada Perusahaan Otomotif Yang Terdaftar Di Bursa Efek Indonesia. Jurnal Jurusan Akuntansi, Politeknik Negeri Semarang.

Priyatno, Duwi. 2014. SPSS 22 Pengolahan Data Terperaktis. Andi : Yogyakarta. 
Sartono, Agus. 1998. Manajemen Keuangan : Teori dan Aplikasi. Edisi Keempat. Yogyakarta: BPFE.

Suad Husnan dan Enny Pudjiastuti. 2012. Dasar-dasar Manajermen Keuangan. Edisi Keenam. UPP STIM YKPN.

Sugiyono. 2015. Metode Penelitian Kuantitatif Kualitatif dan R\&D. Cetakan ke 18. Alfabeta : Bandung.

Sujarweni, Wiratna. 2015. SPSS Untuk Penelitian. Penerbit Pustaka Baru Perss : Yogyakarta.

Sumani dan Lia Rachmawati. 2012. Analisis Struktur Modal Dan Beberapa Faktor Yang Mempengaruhinya Pada Perusahaan Manufaktur Di Bursa Efek Indonesia. Jurnal EMAS Vol. 6, No. 1, November 2012.

Weston, J Fred dan Brigham E.F. 2006. Dasar-dasar Manajemen Keuangan. Terjemahan A.Q Khalid. Jakarta :Erlangga.

Weston, J. Fred dan Thomas E. Copeland. 1996. Financial Management. Edisi 8. Jakarta :Erlangga.

http://jurnal-sdm.blogspot.com/2009/06/teori-struktur-modal.html?m=1. 